\title{
IMPLEMENTASI DATA MINING DENGAN METODE CLUSTERING ALGORITMA K-MEANS UNTUK PENGELOMPOKAN DATA TILANG DI INSTANSI PEMERINTAH
}

\author{
Rini Astuti ${ }^{1}$ \\ Kurweni Ukar \\ Sekolah Tinggi Manajemen Informatika dan Komputer \\ LIKMIJl. Ir. H. Juanda no 96 Bandung \\ riniastuti@likmi.ac.id $^{1}$
}

\begin{abstract}
ABSTRAK
Terjadinya pelanggaran lalu lintas yang sangat banyak dan beragam dapat menyebabkan harus diterbitkannya bukti pelanggaran (tilang) lalu lintas oleh Kepolisian Lalu Lintas yang banyak pula. Pelanggaran terjadi karena ada ketidaksesuaian dengan aturan di Undangundang yang telah ditetapkan yaitu Undang-undang Nomor 22 Tahun 2009 Tentang Lalu Lintas dan Angkutan Jalan. Karena data tilang sangat banyak, maka Pengelolaan data tilang membutuhkan waktu yang lama, sehingga dapat menyebabkan pelayanan sidang tilang untuk menentukan denda kepada pelanggar juga lama.

Salah satu cara untuk mempercepat palayanan adalah dengan memanfaatkan data mining agar data tersebut lebih bermakna dalam bentuk informasi. Data mining adalah proses menerapkan berbagai metode untuk pengelolaan data dengan maksud untuk mengungkap pola-pola tersembunyi. Dengan arti lain Data mining adalah proses untuk penggalian polapola dari data.

Penelitian ini mengimplementasikan data mining metode clustering dengan algoritma kmeans yang merupakan salah satu algoritma pembentukan cluster data, Algoritma ini bekerja dengan cara membagi data ke dalam k-cluster dengan mengelompokkan data berdasarkan kelas-kelas tertentu yang kemudian dirumuskan hasilnya dengan menganalisis banyaknya pasal yang dilanggar dan rata-rata jumlah total pembayaran denda. Dengan adanya sistem pengelolaan data tilang di suatu Instansi Pemerintah ini, diharapkan dapat mempermudah dan mempersingkat waktu pelayananan persidangan baik dalam pengelolaan data, pembayaran denda ataupun proses pengembalian barang bukti tilang.

Sistem informasi pengelompokan data tilang ini menerapkan pengelompokan dengan menggunakan Algoritma K-Means dengan metode clustering, clustering merupakan proses yang digunakan untuk mengelompokkan objek sesuai informasi yang diperoleh dari data yang menyamakan anggota dalam kelasnya, Pendekatan proses pengembangan yang digunakan adalah pendekatan berorientasi objek dengan tool UML dengan model proses prototyping. Melalui sistem ini, dapat memudahkan dalam penyajian informasi berupa jenis tilang terbanyak dan sebagainya, juga mampu meningkatkan kualitas kerja pegawai dalam hal pemanfaatan waktu dan meningkatkan pelayanan.
\end{abstract}

Kata kunci : Tilang, Data Mining, Algoritma K-Means

\section{PENDAHULUAN}

Setiap tahunnya pelanggaran lalu lintas semakin bertambah dan beragam baik dari pelanggaran yang kecil hingga pelanggaran yang memakan denda tertinggi dan memakan korban. Pelanggaran lalu lintas yang diatur dalam Undang-Undang yang telah ditetapkan oleh negara yang berlaku secara sah yaitu Undang-undang Nomor 22 Tahun 2009 Tentang 
Lalu Lintas dan Angkutan Jalan, sudah seharusnya dibenahi agar memberikan efek jera bagi para pelanggar lalu lintas.

Berdasarkan hasil analisis sistem yang berjalan, pengelolaan data tilang masih kurang efektif dan efisien dalam hal melakukan pengecekan dan pencarian data pelanggar serta pembayaran denda, karena proses pengelolaan datanya masih dilakukan secara manual dengan menggunakan Microsof excel, sehingga membutuhkan waktu yang lebih lama, disamping itu terdapat masalah ekternal berupa proses pengelolaan sidang tilang dibawah standar, banyak masyarakat yang mengeluhkan pengelolaan sidang tilang seperti banyaknya perantara calo, suasana antrian yang tidak teratur dan tidak adanya informasi bagi pelanggar mengenai jumlah denda yang harus dibayarkan. Dengan demikian diperlukan sebuah sistem berbasis komputer untuk mendukung pengelolaan data tilang sehingga dapat mempermudah pelayanan kepada pelanggar.

\subsection{Ruang Lingkup}

Ruang lingkup dari penelitian yang dibahas adalah sebagai beikut :

a. Menganalisis kondisi pengelolaan data tilang di suatu Instansi Pemerintah yang sedang berjalan.

b. Mengimplementasikan data mining metode slustering dengan algoritma K-Means untuk Sistem Pengelolaan Data Tilang Di suatu Instansi Pemerintah. untuk mempermudah pelayanan kepada masyarakat sesuai dengan kebutuhan.

\subsection{Tujuan Penelitian}

Tujuan dilaksanakannya penelitian adalah :

a. Merancang sistem pengelolaan data tilang sesuai dengan kebutuhan.

b. Memudahkan pencarian informasi tilang dengan menerapkan data mining menggunakan algoritma K-Means pada metode clustering di Instasi Pemerintah.

\section{LANDASAN TEORI}

\subsection{Model Prototyping}

Perencanaan iterasi pembuatan prototipe dilakukan secara cepat. Setelah itu dilakukan pemodelan dalam bentuk "rancangan cepat". Pembuatan rancangan cepat berdasarkan pada representasi aspek-aspek perangkat lunak yang akan terlihat oleh para end user (misalnya rancangan antarmuka pengguna atau format tampilan). Rancangan cepat merupakan dasar untuk memulai konstruksi pembuatan prototipe.

Menurut Pressman [6], model prototyping dimulai dari tahap komunikasi. Tim pengembang melakukan pertemuan dengan para stakeholder untuk menentukan kebutuhan sistem yang saat itu diketahui dan untuk menggambarkan area-area dimana definisi kebutuhan ditentukan untuk iterasi selanjutnya.

Prototipe kemudian diserahkan kepada para stakeholder untuk mengevaluasi prototype yang telah dibuat sebelumnya dan memberikan umpan-balik yang akan digunakan untuk memperbaiki spesifikasi kebutuhan. Iterasi terjadi saat pengembang melakukan perbaikan terhadap prototipe tersebut. 


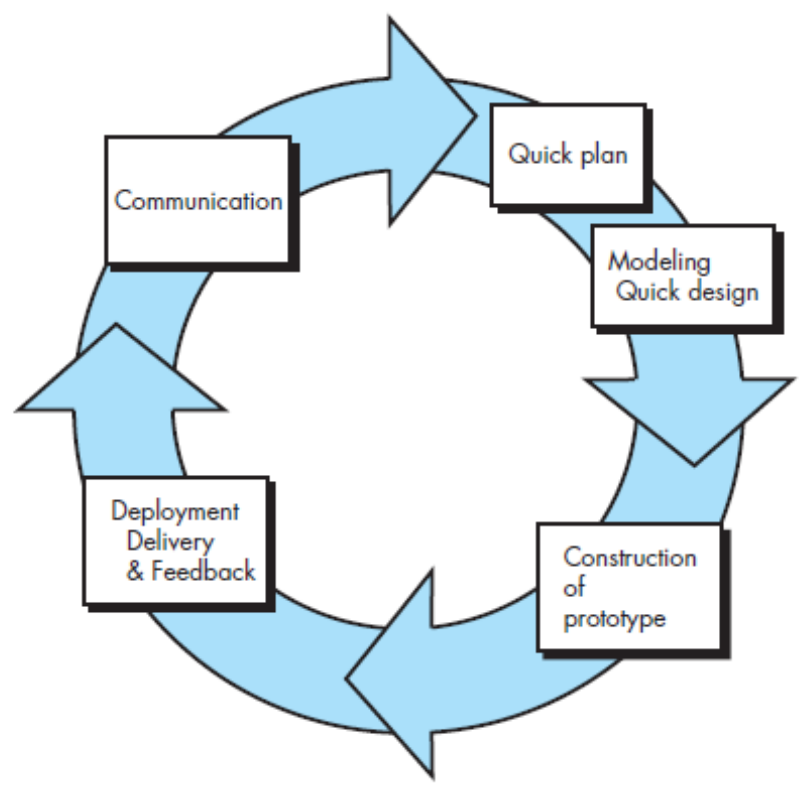

Gambar 1

Model prototyping [6]

\subsection{Algoritma K-Means}

Metode clustering adalah salah satu proses data mining untuk pengelompokan. Terdapat berbagai jenis pengelompokan diantaranya adalah K-means dan Algoritma C45. Menurut Suyanto 2017 dalam bukunya yang berjudul " Data Mining Untuk Klasifikasi Dan Klasterisasi Data" mengatakan Metode k-means merupakan algoritma klasterisasi yang paling tua dan metode yang paling banyak digunakan dalam berbagai aplikasi kecil hingga menengah karena kemudahan implementasinya. Pada (Wu 2012) dinyatakan bahwa riset tentang k-means telah dilakukan banyak peneliti dari beragam disiplin ilmu sejak tahun 1950-an, diantaranya adalah Lloyd (1957, 1982), Forgey (1965), Friedman dan Rubin (1967) serta MacQueen (1967).

Ide dasar algoritma k-means sangatlah sederhana, yaitu meminimalkan Sum Of Squared Error (SSE) antara objek-objek data dengan sejumlah k centroid. Algoritma kmeans bekerja dengan empat langkah, yang diilustrasikan dalam pseudo code dibawah ini.

a. Pertama, dari himpunan data yang akan diklasterisasi, dipilih sejumlah k objek secara acak sebagai centroid awal.

b. Kedua, setiap objek yang bukan centroid dimasukkan ke klaster terdekat berdasarkan ukuran jarak tertentu.

c. Ketiga, setiap centroid diperbarui berdasarkan rata-rata dari objek yang ada di dalam setiap klaster.

d. Keempat, langkah kedua dan ketiga tersebut diulang-ulang (di-iterasi) sampai semua centroid yang dihasilkan dalam iterasi saat ini sama dengan semua centroid yang dihasilkan pada iterasi sebelumnya.

Algoritma k-means membutuhkan waktu yang relatif cepat. Kompleksitas waktu kmeans adalah $\mathrm{O}(\mathrm{nkt})$, dimana $\mathrm{n}$ adalah jumlah keseluruhan objek data, $\mathrm{k}$ adalah jumlah klaster, dan $\mathrm{t}$ adalah jumlah iterasi. Biasanya k maupun $\mathrm{t}$ jauh lebih kecil dibanding $\mathrm{n}$. Jadi jika ada seribu objek data yang diklasterisasi ke dalam dua klaster memerlukan sepuluh iterasi, maka hanya memerlukan waktu 1000 × 2 × $10=20000$ operasi komputasi. Jika menjalankan k-means sepuluh kali centroid awal yang berbeda-beda, maka hanya memerlukan waktu 200 ribu operasi komputasi (Suyanto, 2017). 
Sedangkan menurut Sri Andayani dalam penelitiannya yang berjudul "Pembentukan cluster dalam Knowledge Discovery in Database dengan Algoritma K-Means" mengatakan Algoritma K-Means adalah algoritma clustering yang paling popular dan banyak digunakan dalam dunia industri. Algoritma ini disusun atas dasar ide yang sederhana. Ada awalnya ditentukan berapa cluster yang akan dibentuk. Sebarang obyek atau elemen pertama dalam cluster dapat dipilih untuk dijadikan sebagai titik tengah (centroid point) cluster.

Algoritma K-Means selanjutnya akan melakukan pengulangan langkah-langkah berikut sampai terjadi kestabilan (tidak ada obyek yang dapat dipindahkan):

a. Menentukan koordinat titik tengah setiap cluster,

b. Menentukan jarak setiap obyek terhadap koordinat titik tengah,

c. Mengelompokkan obyek-obyek tersebut berdasarkan pada jarak minimumnya.

Ide dasar algoritma k-means sangatlah sederhana, yaitu meminimalkan Sum of Squared Error (SSE) antara objek-objek data dengan sejumlah k centroid. Algoritma kmeans bekerja dengan empat langkah, yang diilustrasikan dalam pseudo code dibawah ini.

a. Pertama, dari himpunan data yang akan diklasterisasi, dipilih sejumlah k objek secara acak sebagai centroid awal.

b. Kedua, setiap objek yang bukan centroid dimasukkan ke klaster terdekat berdasarkan ukuran jarak tertentu.

c. Ketiga, setiap centroid diperbarui berdasarkan rata-rata dari objek yang ada di dalam setiap klaster.

d. Keempat, langkah kedua dan ketiga tersebut diulang-ulang (diiterasi) sampai semua centroid yang dihasilkan dalam iterasi saat ini sama dengan semua centroid yang dihasilkan pada iterasi sebelumnya.

\subsection{Clustering}

Clustering atau klasterisasi merupakan pengelompokan record. Di dalam buku karya Suyanto yang berjudul "Data Mining Untuk Klasifikasi dan Klasterisasi Data" dijelaskan : "Pada data tertentu, teknik klasterisasi atau clustering biasa digunakan untuk mereduksi data. Ide dasarnya sangatlah sederhana, objek data dipartisi kedalam sejumlah kelompok atau cluster dimana objek-objek yang sangat mirip dikelompokkan kedalam klaster yang sama sedangkan objek-objek yang berbeda di klaster yang berbeda".[7]

Di dalam buku "Minning of Massive Datasets" karya Lescovec Jure et al. [3] menjelaskan :

"Clustering is the process of examining a collection of "points," and grouping the points into "clusters" according to some distance measure. The goal is that points in the same cluster have a small distance from one another, while points in different clusters are at a large distance from one another". [3]

Dijelaskan bahwa clustering adalah proses pengujian sekelompok titik dan mengelompokkan titik ke dalam cluster berdasarkan jarak. Tujuannya adalah mencari jarak terdekat akan memiliki cluster yang sama sementara jarak lainnya dengan cluster berbeda.

K-means Clustering merupakan salah satu metode data clustering non-hirarki yang mengelompokan data dalam bentuk satu atau lebih cluster/kelompok. Data-data yang memiliki karakteristik yang sama dikelompokan dalam satu cluster/kelompok dan data yang memiliki karakteristik yang berbeda dikelompokan dengan cluster/kelompok yang lain sehingga data yang berada dalam satu cluster/kelompok memiliki tingkat variasi yang kecil.

Langkah-langkah melakukan clustering dengan metode K-Means adalah sebagai berikut :

a. Pilih jumlah cluster $\mathrm{k}$. 
b. Inisialisasi k pusat cluster ini bisa dilakukan dengan berbagai cara. Namun yang paling sering dilakukan adalah dengan cara random. Pusat-pusat cluster diberi nilai awal dengan angka-angka random,

c. Alokasikan semua data atau objek ke cluster terdekat. Kedekatan dua objek ditentukan berdasarkan jarak kedua objek tersebut. Demikian juga kedekatan suatu data ke cluster tertentu ditentukan jarak antara data dengan pusat cluster. Dalam tahap ini perlu dihitung jarak tiap data ke tiap pusat cluster. Jarak paling antara satu data dengan satu cluster tertentu akan menentukan suatu data masuk dalam cluster mana. Untuk menghitung jarak semua data ke setiap titik pusat cluster dapat menggunakan teori jarak Euclidean yang dirumuskan sebagai berikut :

dimana:

$$
D(i, j) \sqrt{\left(X_{1 i}-X_{1 j}\right)^{2}+\left(X_{2 i}-X_{2 j}\right)^{2}+\cdots+\left(X_{k i}-X_{k j}\right)^{2}}
$$

D (i,j) : Jarak data ke i ke pusat cluster $\mathrm{j}$

Xki : Data ke i pada atribut data ke $\mathrm{k}$

Xkj : Titik pusat ke $\mathrm{j}$ pada atribut ke $\mathrm{k}$

d. Hitung kembali pusat cluster dengan keanggotaan cluster yang sekarang. Pusat cluster adalah rata-rata dari semua data atau objek dalam cluster tertentu. Jika dikehendaki bisa juga menggunakan median dari cluster tersebut. Jadi rata-rata (mean) bukan satu-satunya ukuran yang bisa dipakai.

e. Tugaskan lagi setiap objek memakai pusat cluster yang baru. Jika pusat cluster tidak berubah lagi maka proses clustering selesai. Atau, kembali ke langkah nomor 3 sampai pusat cluster tidak berubah lagi. (Ong, 2013)

\section{PROSEDUR PENGELOLAAN TILANG}

Tilang adalah Bukti Pelanggaran. Fungsi tilang itu sendiri adalah sebagai undangan kepada pelanggar lalu lintas untuk menghadiri sidang di pengadilan negeri, serta sebagai tanda bukti penyitaan atas barang yang disita oleh polantas dari pelanggar. Barang bukti yang boleh disita oleh Polantas adalah SIM, STNK, STCK, dan kendaraan bermotor.

Prosedur tilang yang terjadi di Unit Lalu lintas adalah sebagai berikut :

a. Tilang diambil oleh Bintara Tilang Polsek dari Satuan Lalu lintas Polrestabes.

b. Masing-masing buku Tilang di cek kelengkapannya. Satu buku tilang berisi 5 buah tilang. 1 buah tilang terdiri dari 5 lembar warna :

1) Warna MERAH untuk pelangggar

2) Warna BIRU juga untuk pelanggar

3) Warna HIJAU untuk Pengadilan

4) Warna KUNING untuk arsip Polisi

5) Warna PUTIH untuk Kejaksaan.

c. Setelah diperiksa, buku Tilang diberi stempel kesatuan untuk menunjukkan Tilang tersebut digunakan oleh Kesatuan mana, serta stempel Staff untuk menandakan bahwa Tilang tersebut sah diketahui oleh Kapolsek.

d. Tilang yang digunakan oleh Polantas Opsional dikembalikan kepada Bintara Tilang di Polsek untuk dikompulir, dan disetor dalam jangka waktu kurang lebih 1 minggu.

e. Penyelesaian Alternatif III, pelanggar dapat datang ke satuan yang menilang, selama lembar Tilang dan Barang Bukti yang disita masih berada Polsek adalah :

f. Mulai tanggal tilang sampai dengan H-4 tanggal sidang, Barang Bukti dan Tilang masih di Polsek, pelanggar dapat menitipkan denda di Polsek. Besar denda yang diterapkan sama dengan yang diterapkan di Pengadilan. 
g. Mulai H-3 sampai dengan h-1 tanggal sidang, Barang Bukti dan Tilang sudah diserahkan ke satuan lebih atas, yaitu Satlantas Polresta/Polrestabes. Jadi bagi pelanggar yang mau nitip denda, datangnya ke Satlantas Polrestabes bagian Tilang.

h. Hari $\mathrm{H}$ atau tepat tanggal sidang, lembar tilang dan Barang Bukti berada di Pengadilan, dan pelanggar menyelesaikan dendanya di pengadilan.

i. Apabila sampai hari $\mathrm{H}$, pelanggar tidak punya waktu menyelesaikan Tilang, tidak masalah, Namun tilang dan Barang Bukti sudah berpindah ke Kejaksaan. Jadi pelanggar menyelesaikannya disana.

j. Tilang dikembalikan ke Sat Lantas Polrestabes lengkap dengan barang bukti atau uang titipan denda dari pelanggar.

Terdapat 4 alternatif penyelesaian tilang sebagai berikut :

a. Alternatif I

Pelanggar mengakui pelanggaran yang telah dilakukan, dan akan menyelesaikan perkara Tilang di Pengadilan. Alternatif ini pelanggar akan menerima lembar warna Merah.

b. Alternatif II

Pelanggar mengakui pelanggaran yang telah dilakukan, dan akan menyelesaikan denda Tilang di bank BRI. Alternatif ini, petugas akan menulis denda tertinggi yang dikenakan oleh UU pada lembar tilang, dan pelanggar akan menerima lembar berwarna Biru.

c. Alternatif III

Pelanggar mengakui pelangggaran yang telah dilakukan, dan akan menitipkan denda kepada petugas Polri. Alternatif ini ditujukan bagi pelanggar dari luar kota yang tidak memiliki waktu untuk menyelesaikan sidang di Pengadilan maupun di bank BRI. Alternatif ini pelanggar tidak akan menerima lembar tilang, karena saat itu juga barang bukti langsung dikembalikan.

d. Alternatif IV

Pelanggar tidak mengakui pelanggaran yang ditujukan kepadanya, dan pelanggar tidak mau tanda tangan. Penyelesaian alternatif IV ini akan diselesaikan di pengadilan dengan mempertemukan petugas yang menilang dengan pelanggar yang merasa tidak bersalah. Penyelesaian alternatif ini, pelanggar akan menerima dua lembar sekaligus, yaitu Merah dan Biru (Kamila, 2015).

\section{METODOLOGI DAN PEMBAHASAN}

\subsection{Metodologi}

Penelitian ini bersifat kualitatif dengan melakukan observasi (participant observation) dengan melihat penanganan tilang di Instansi Pemerintah. Adapun yang dimaksud dengan penelitian kualitatif yaitu metode penelitian yang digunakan untuk meneliti pada kondisi objek alamiah, (sebagai lawannya eksperimen) dimana peneliti adalah sebagai instrumen kunci, teknik pengumpulan data dilakukan secara trianggulasi (gabungan), analisis data bersifat induktif, dan hasil penelitian kualitatif lebih menekankan makna daripada generalisasi.

Setelah melakukan pengumpulan data dan analisis data tahapan selanjutnya adalah penerapan algoritma k-means dengan membagi data kedalam cluster-cluster tertentu dan pengelompokannya menjadi satu.

\subsection{Analisis Sistem}

Analisa sistem yang berjalan dilakukan dengan tujuan untuk mengetahui proses kerja yang sedang dikerjakan pada sistem tersebut. Saat ini sistem dan prosedur tilang melibatkan tiga instansi yang berbeda dan untuk menyatukannya diperlukan banyak waktu dan biaya, oleh karena pada penelitian ini hanya mengevaluasi kebutuhan sistem pada pihak terkait langsung saja, karena pada di pihak lain sudah menggunakan sistem e-tilang untuk mencatat 
data-data pelanggar yang ditilang dan output yang dihasilkan berupa file excel yang nanti akan diserahkan ke pihak terkait untuk diputuskan besarnya denda dan biaya perkara tilang secara manual, sehingga tidak memungkinkan dibuat sistem yang saling terintegrasi satu sama lain.

\subsection{Pemodelan Fungsional}

Alat bantu yang digunakan untuk memodelkan fungsional sistem ini adalah use case diagram. Pemodelan fungsional dibuat berdasarkan kebutuhan sistem sehingga proses pengelompokan dan kebutuhan informasi dapat terpenuhi secara efisien dan efektif.

Aktor yang terlibat pada use case ini adalah user dan Admin. Gambar 2 menjelaskan model fungsional sistem pengelompokan yang terdiri dari use case login untuk autentikasi user yang berhak dan admin. Use case Kelola pelanggar untuk menyimpan data pelanggar berdasarkan No Identitas.Olah data tilang untuk menyimpan dan menangani data tilang dengan cara menimport data. Use case clustering dengan K-Means digunakan untuk mengelompokkan data tilang berdasarkan kriteria tertentu. Dan use case Pelaporan untuk menghasilkan laporan yang dibutuhkan.

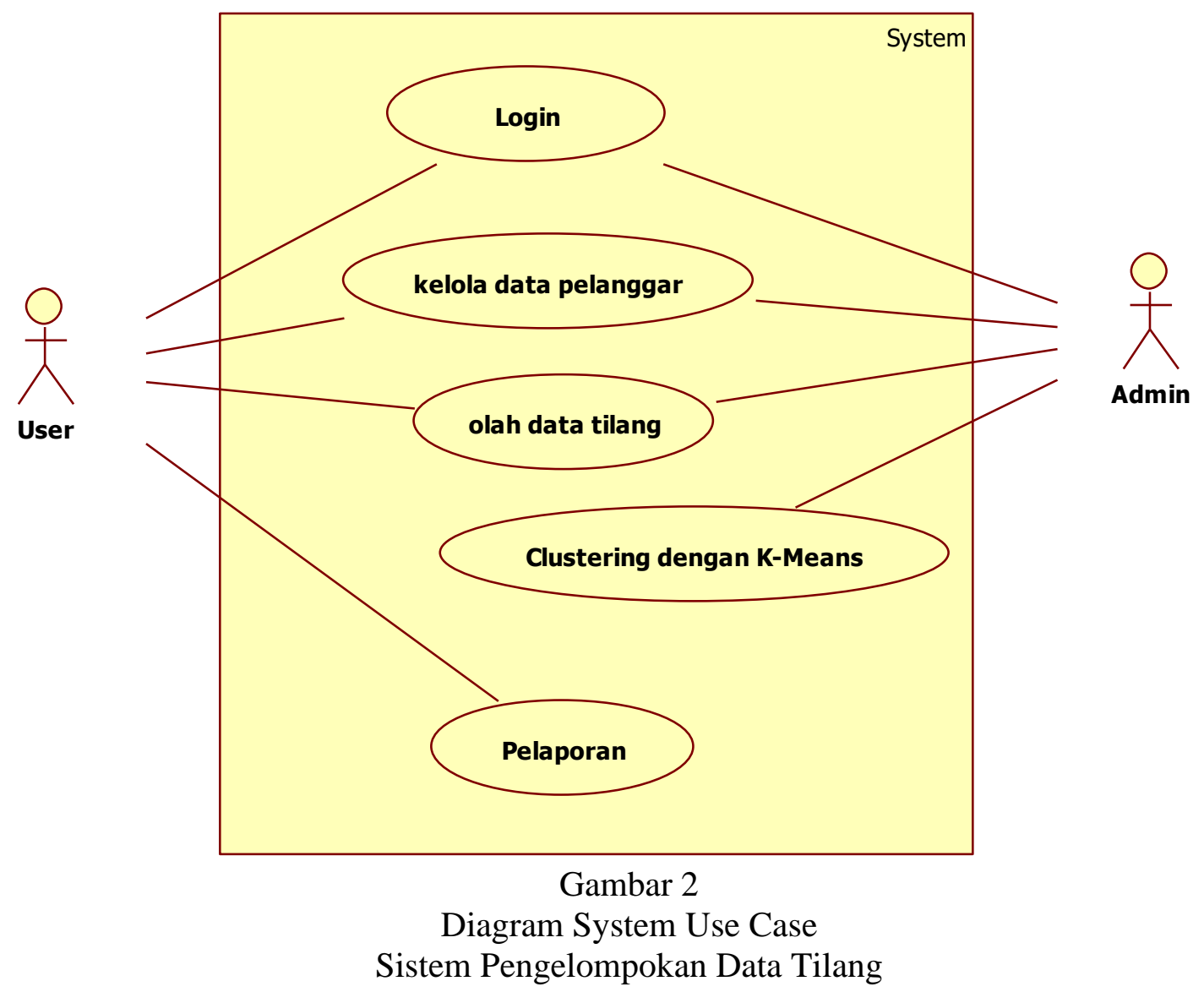

\subsection{Proses Clustering dengan algoritma k-means}

Keluaran dari k-means bergantung pada centroid (titik tengah) awal yang ditentukan secara acak. Oleh karena itu, dalam aplikasi harus menjalankan k-means beberapa kali dengan centroid awal yang berbeda-beda untuk menghasilkan centroid akhir yang paling bagus. Adapun tahapan yang dilakukan sesuai dengan algoritma sebagai berikut : 


\section{ALGORITMA K-MEANS CLUSTERING \\ $k$-means $(\mathrm{D}, \mathrm{k})$}

pilih sejumlah k objek secara acak dari himpunan data D sebagai centroid

awal

repeat

for semua objek di dalam D

masukkan setiap objek yang bukan centroid ke klaster yang paling

dekat diantara k klaster yang ada

end

perbarui setiap centroid dengan menghitung rata-rata dari semua objek yang berada di dalam klaster tersebut

until tidak ada perubahan centroid

Gambar 3 adalah contoh data training yang akan dikelompokkan yang sudah tersimpan dalam spreadsheet. Data tersebut di-import dari Sistem Aplikasi Pengelompokan Tilang kemudian disimpan ke dalam basis data. Dengan Algoritma K-Means dihasilkan Laporan pengelompokan sesuai dengan ketentuan dan kriteria yang ditetapkan.

\begin{tabular}{|c|c|c|c|c|c|c|c|c|c|c|}
\hline No & $\begin{array}{c}\text { NOMOR } \\
\text { REGISTER } \\
\text { TILANG }\end{array}$ & $\begin{array}{c}\text { TGL } \\
\text { PERKARA }\end{array}$ & FORM & $\begin{array}{c}\text { NOMOR } \\
\text { PEMBAYARAN }\end{array}$ & $\begin{array}{c}\text { NRP } \\
\text { PETUGAS }\end{array}$ & $\begin{array}{c}\text { NAMA } \\
\text { PETUGA } \\
\mathrm{S}\end{array}$ & NAMA & ALAMAT & PASAL & $\begin{array}{c}\text { BARANG } \\
\text { BUKTI }\end{array}$ \\
\hline 1 & 2 & 3 & 4 & \begin{tabular}{|l|}
5 \\
\end{tabular} & 6 & $\begin{array}{l}7 \\
\end{array}$ & 8 & 9 & 10 & 11 \\
\hline 1 & C6125430 & $16 / 12 / 2017$ & Biru & 2955000966562 & 79051938 & NTO SIHAD & A. KUSNADI & SERANG & NONKTL 1 pasal: & 11|SIM A \\
\hline 2 & C6125440 & & Merah & & & & AHMAD BAD & RIAU & 307 UULAJ & STNK \\
\hline 3 & C6125441 & & Merah & & & & JUMAIRI AH & JATIM & 307 UULAJ & STNK \\
\hline 4 & C6125442 & & Merah & & & & MUKDAR & GRESIK & 307 UULAJ & STNK \\
\hline 5 & C6125446 & $16 / 12 / 2017$ & Merah & 2768000987933 & 79051938 & NTO SIHAD & SUBAGYO & CIREBON & NONKTL 1 pasal: & 20|STNK \\
\hline 6 & C6125447 & $16 / 12 / 2017$ & Merah & 2768000987997 & 79051938 & NTO SIHAD & MUHAMMA & PALEMBANG & NONKTL 2 pasal: & 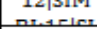 \\
\hline 7 & C6125448 & $16 / 12 / 2017$ & Merah & 2768000987998 & 79051938 & NTO SIHAD & M.FAJAR SAI & BREBES & NONKTL 1 pasal: & $20 \mid$ STNK \\
\hline 8 & C6125449 & $20 / 12 / 2017$ & Merah & 2768000988632 & 79051938 & NTO SIHAD & YOYO WALU & CIREBON & NONKTL 1 pasal: & $20 \mid$ STNK \\
\hline 9 & C6125450 & $20 / 12 / 2017$ & Merah & 2768000988633 & 79051938 & NTO SIHAD & ALI USMAN & BOJONEGORO & NONKTL 1 pasal: & $20 \mid$ STNK \\
\hline 10 & C6122433 & $21 / 12 / 2017$ & Biru & 2955000981508 & 82100211 & UMM GUMI & BOIN & CIREBON & NONKTL 1 pasal: & 20|STNK \\
\hline 11 & C6122434 & & Merah & & & & HARJONOS & JEPARA & 307 UUL & STNK \\
\hline 12 & C6122435 & & Merah & & & & SALUKI & CIREBON & 288(2)UUL & STNK \\
\hline 13 & C6122437 & & Merah & & & & SUPRIYONO & KEBUMEN & 285UUL & STNK \\
\hline 14 & C6122438 & & Merah & & & & IWAN TARU & TEGAL & 285 UUL & STNK \\
\hline 15 & C6122439 & & Merah & & & & TEGUH PAJA & CIAMIS & $288(2)$ UUL & STNK \\
\hline
\end{tabular}

\begin{tabular}{|c|c|c|c|c|c|c|c|c|c|c|c|c|c|}
\hline $\begin{array}{c}\text { JENIS } \\
\text { KENDAR } \\
\text { AAN }\end{array}$ & $\begin{array}{c}\text { NOMOR } \\
\text { POLISI }\end{array}$ & $\begin{array}{c}\text { UANG } \\
\text { TITIPA } \\
\text { N }\end{array}$ & $\begin{array}{c}\text { KODE } \\
\text { SATKER } \\
\text { PN }\end{array}$ & \begin{tabular}{|l} 
NOMOR \\
PERKARA / \\
PUTUSAN
\end{tabular} & $\begin{array}{l}\text { NAMA } \\
\text { HAKIM }\end{array}$ & $\begin{array}{c}\text { NAMA } \\
\text { PANITERA }\end{array}$ & $\begin{array}{c}\text { KODE } \\
\text { SATKER } \\
\text { KEJAKSA } \\
\text { AN }\end{array}$ & $\begin{array}{c}\text { TGL } \\
\text { SIDANG / } \\
\text { TGL } \\
\text { PUTUSAN }\end{array}$ & $\begin{array}{c}\text { HADIR / } \\
\text { VERSTE } \\
\text { K }\end{array}$ & DENDA & \begin{tabular}{|c|} 
ONG \\
KOS \\
PERK \\
ARA
\end{tabular} & TGL BYR & $\begin{array}{c}\text { SISA } \\
\text { TITIP } \\
\text { AN }\end{array}$ \\
\hline 12 & 13 & 14 & 15 & 16 & 17 & 18 & 19 & 20 & 21 & 22 & 23 & 25 & 26 \\
\hline $2 \mid$ MOBIL & A8174F & 150,000 & 400477 & 1/Pid.LL/2018/ & ING RESPAN & ARIYANTO, S & 10.19 & 05-01-2018 & VERSTEK & 149000 & 1000 & 16-12-2017 & 0 \\
\hline TRAILER & H1805DP & & 400477 & 2/Pid.LL/2018/ & ING RESPAN & ARIYANTO, S & 10.19 & $05-01-2018$ & VERSTEK & 99000 & 1000 & & \\
\hline TRAILER & H1996CF & & 400477 & 3/Pid.LL/2018/ & ING RESPAN & ARIYANTO, S: & 10.19 & 05-01-2018 & VERSTEK & 99000 & 1000 & & \\
\hline TRUCK & W9275UD & & 400477 & 4/Pid.LL/2018/ & ING RESPAN & ARIYANTO, S & 10.19 & 05-01-2018 & VERSTEK & 99000 & 1000 & & \\
\hline $6 \mid$ TRUCK & E8498AM & & 400477 & 5/Pid.LL/2018/ & ING RESPAN & ARIYANTO, S: & 10.19 & $05-01-2018$ & VERSTEK & 99000 & 1000 & & \\
\hline 6|TRUCK & B9047FXR & & 400477 & 6/Pid.LL/2018/ & ING RESPAN & ARIYANTO, S & 10.19 & $05-01-2018$ & VERSTEK & 124000 & 1000 & & \\
\hline $8 \mid$ TRONT & B9755UIN & & 400477 & 7/Pid.LL/2018/ & ING RESPAN & ARIYANTO, S: & 10.19 & 05-01-2018 & VERSTEK & 124000 & 1000 & & \\
\hline 6|TRUCK & E8273KU & & 400477 & 8/Pid.LL/2018/ & ING RESPAN & ARIYANTO, S & 10.19 & $05-01-2018$ & VERSTEK & 99000 & 1000 & & \\
\hline $8 \mid$ TRONT & H1646ES & & 400477 & 9/Pid.LL/2018/ & ING RESPAN & ARIYANTO, S & 10.19 & $05-01-2018$ & VERSTEK & 99000 & 1000 & & \\
\hline 6|TRUCK & E8908AS & 150,000 & 400477 & 10/Pid.LL/2018 & ING RESPAN & ARIYANTO, S & 10.19 & $05-01-2018$ & VERSTEK & 149000 & 1000 & $21-12-2017$ & 0 \\
\hline PICK UP & K 1794 IC & & 400477 & 11/Pid.LL/2018 & ING RESPAN & ARIYANTO, S: & 10.19 & 05-01-2018 & VERSTEK & 74000 & 1000 & & \\
\hline TRUK & E $9552 \mathrm{HB}$ & & 400477 & 12/Pid.LL/2018 & ING RESPAN & ARIYANTO, S & 10.19 & $05-01-2018$ & VERSTEK & 99000 & 1000 & & \\
\hline MIKROB & AA $1735 \mathrm{CD}$ & & 400477 & 13/Pid.LL/2018 & ING RESPAN & ARIYANTO, S & 10.19 & $05-01-2018$ & VERSTEK & 74000 & 1000 & & \\
\hline PICK UP & $\mathrm{E} 8594 \mathrm{AQ}$ & & 400477 & 14/Pid.LL/2018 & ING RESPAN & ARIYANTO, S & 10.19 & $05-01-2018$ & VERSTEK & 74000 & 1000 & & \\
\hline TRUK & E $9101 \mathrm{MF}$ & & 400477 & 15/Pid.LL/2018 & ING RESPAN & ARIYANTO, S: & 10.19 & 05-01-2018 & VERSTEK & 99000 & 1000 & & \\
\hline
\end{tabular}

Gambar 3

Contoh Data training 


\section{PERANCANGAN DAN IMPLEMENTASI SISTEM}

Perancangan dalam pembangunan sistem informasi merupakan upaya untuk mengkonstruksi sebuah sistem yang memberikan kepuasan (mungkin informal) akan spesifikasi kebutuhan fungsional, memenuhi target, memenuhi kebutuhan secara implisit atau eksplisit dari segi performansi maupun penggunaan sumber daya, kepuasan batasan pada proses desain dari segi biaya, waktu, dan perangkat.Hasil dari perancangan sistem pada penelitian ini adalah skema database dan desain antar muka sistem.

Skema database adalah model transformasi pemodelan konseptual data yang dibutuhkan sistem ini, Gambar 4 menunjukkan skema database sistem.

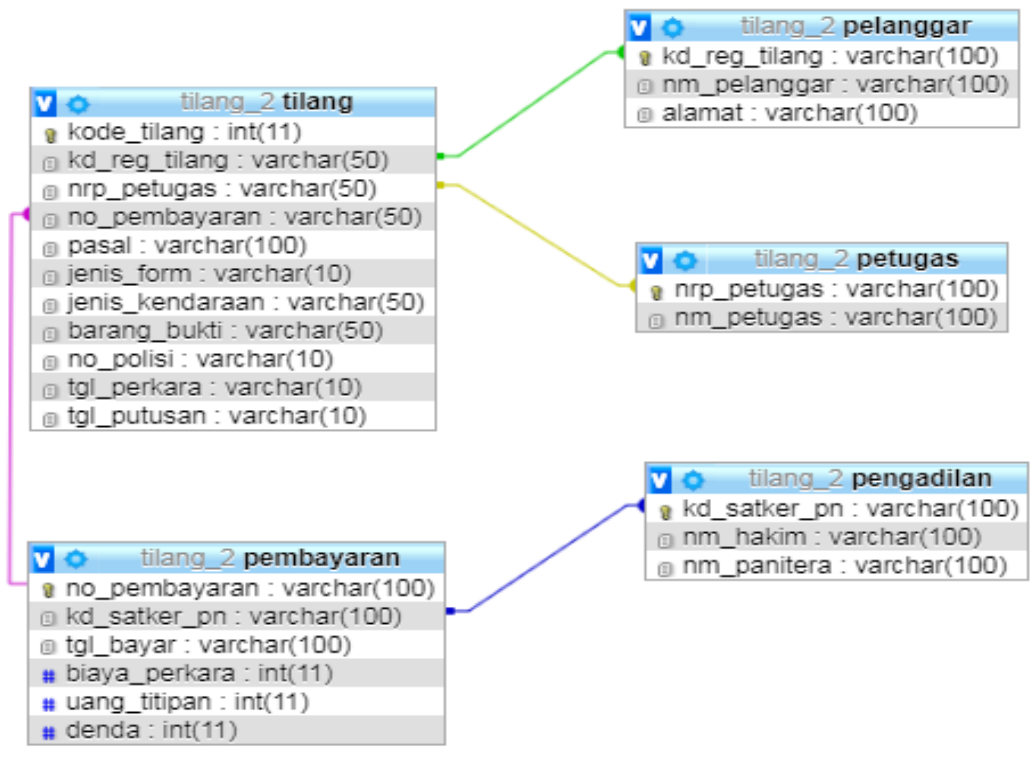

Gambar 4

Skema Database

Perancangan antarmuka dibuat mulai dari halaman awal, halaman login, halaman input sampai halaman output. Gambar 5 s/d 9 adalah beberapa rancangan antar muka yang dibuat sesuai dengan kebutuhan sistem ini. Sedangkan Gambar $10 \mathrm{~s} / \mathrm{d} 11$ merupakan contoh tampilan implementasi dari konstruksi sistem pengelompokan data Tilang.

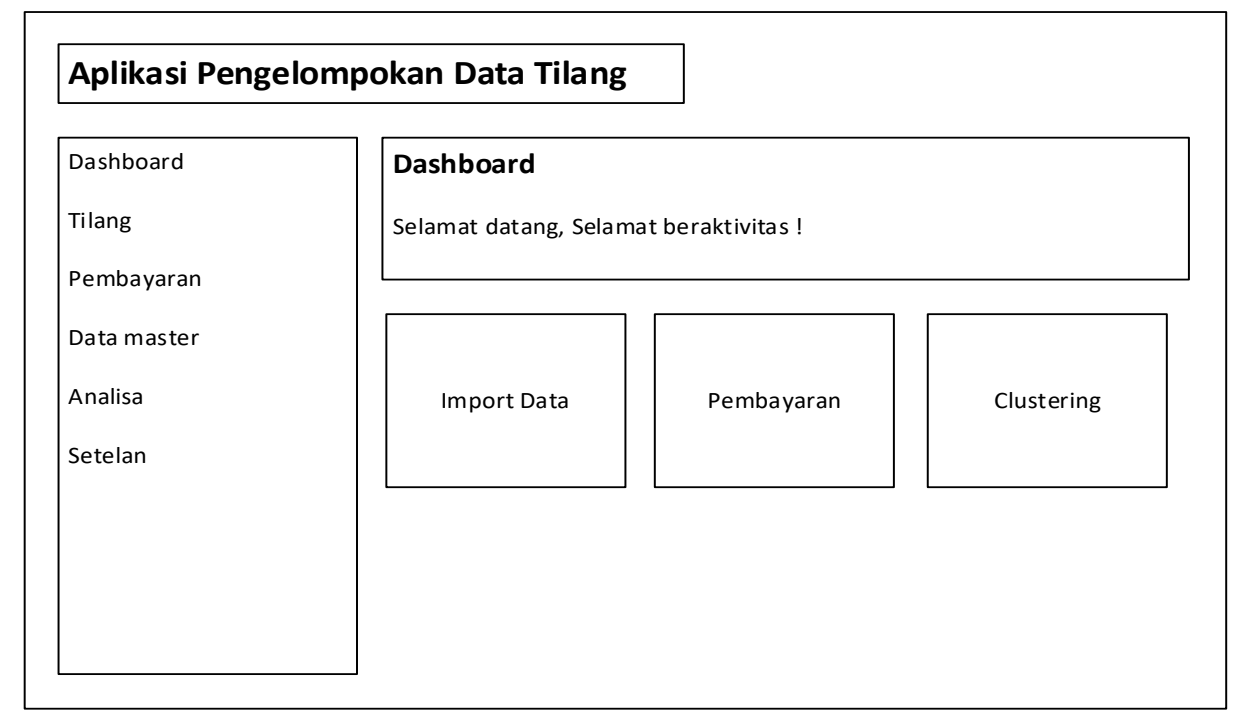

Gambar 5

Desain Tampilan Halaman Depan (Dashboard) 


\section{Aplikasi Pengelompokan Data Tilang}

\begin{tabular}{|l|}
\hline Dashboard \\
Tilang \\
Pembayaran \\
Data master \\
Analisa \\
Setelan \\
\end{tabular}

\section{Tilang !}

Berisi tentang data tilang, pelanggar, petugas, barang bukti, dan lain-lain

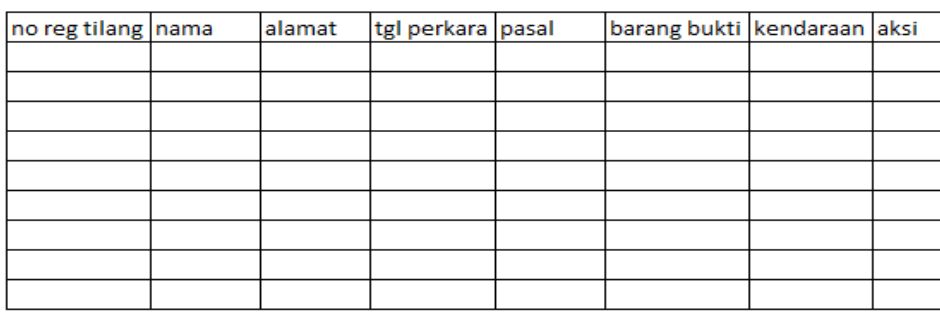

Gambar 6

Desain Tampilan Menu

\section{Aplikasi Pengelompokan Data Tilang}

\begin{tabular}{|l|}
\hline Dashboard \\
Tilang \\
Pembayaran \\
Data master \\
- $\quad$ pelanggar \\
- petugas \\
pengadilan \\
Analisa K-MEANS \\
Setelan
\end{tabular}

Analisa K-MEANS !

Berisi tentang analisa perhitungan $\mathrm{k}$-means clustering

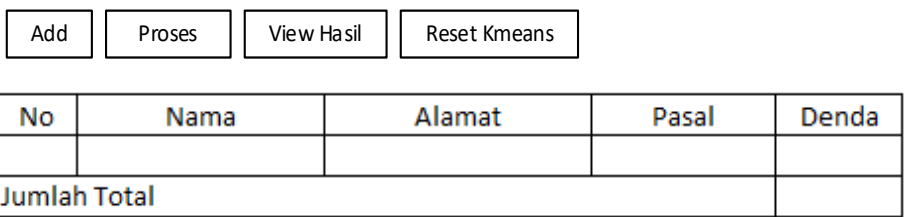

Gambar 7

Tampilan Analisis K-Means 


\section{Aplikasi Pengelolmpokan Data Tilang}

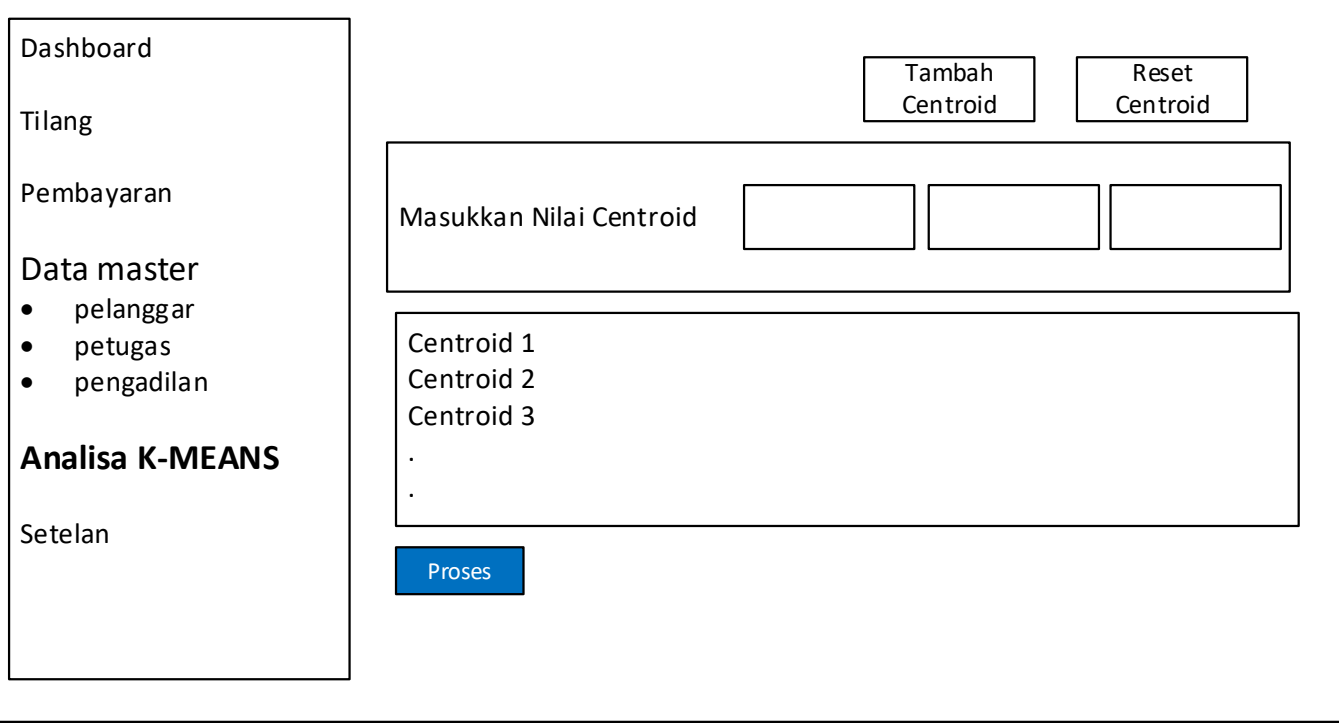

Gambar 8

Tampilan Pengisian Centroid Awal

\section{Aplikasi Pengelompokan Data Tilang}

\begin{tabular}{|l|}
\hline Dashboard \\
Tilang \\
Pembayaran \\
Data master \\
- $\quad$ pelanggar \\
- $\quad$ petugas \\
pengadilan \\
Analisa K-MEANS \\
Setelan
\end{tabular}

\begin{tabular}{|l|l|l|}
\hline \multicolumn{2}{|l|}{ Ini adalah Hasil Analisa Clustering } & Print \\
\hline Hasil Cluster 1 & Hasil Cluster 2 & Hasil Cluster 3 \\
\hline Cluster 1 terdiri dari ... Orang & Cluster 2 terdiri dari ... Orang & Cluster 3 terdiri dari ... Orang \\
\hline Yang berasal dari Alamat : & Yang berasal dari Alamat : & Yang berasal dari Alamat : \\
\hline & & \\
\hline Dan melanggar Pasal: & Dan melanggar Pasal: & Dan melanggar Pasal: \\
\hline & & \\
\hline Dengan rata-rata denda Rp. & Dengan rata-rata denda Rp. & Dengan rata-rata denda Rp. \\
\hline
\end{tabular}

Gambar 9

Tampilan Hasil Proses Iterasi K-Means 


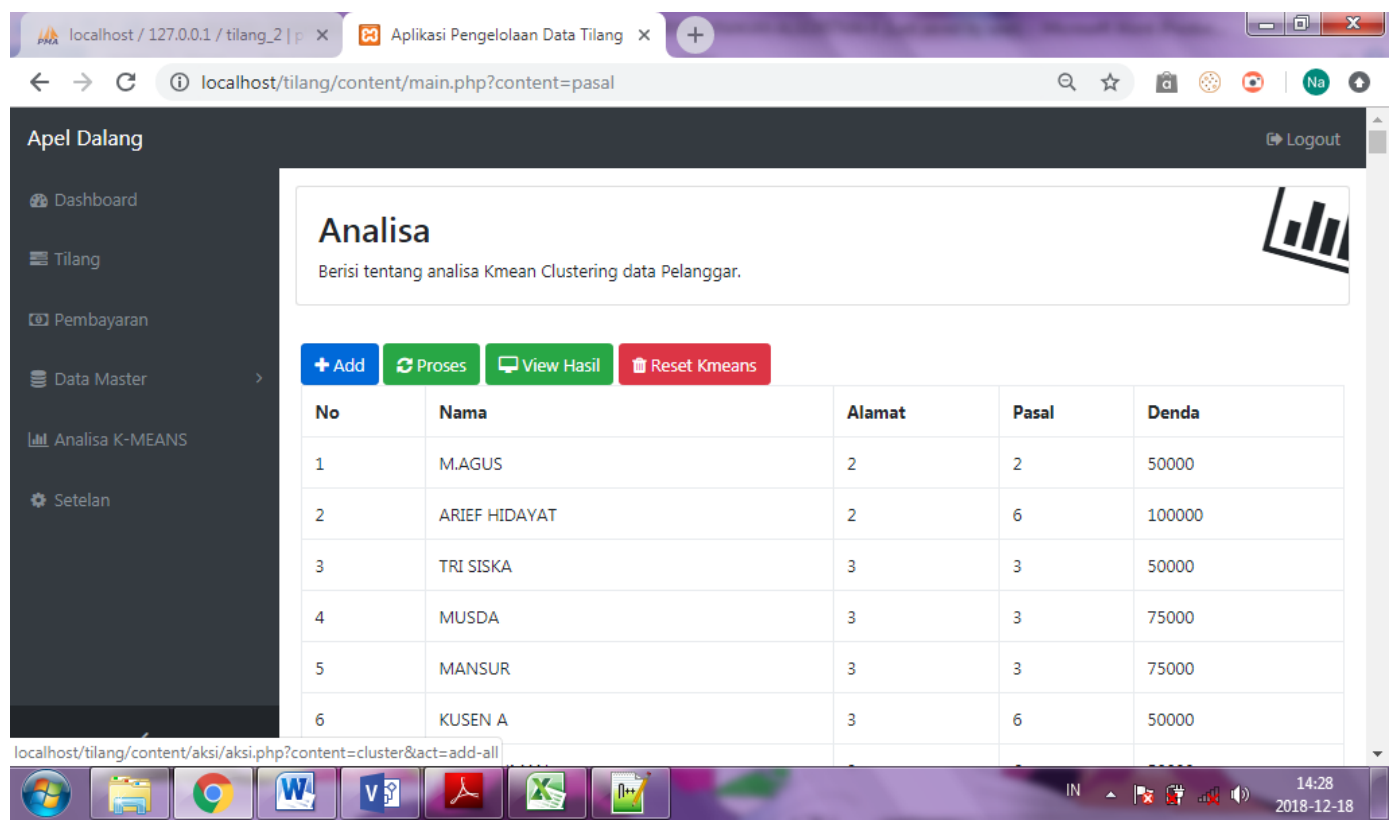

Gambar 10

Implementasi Halaman Penambahan Data Analisa K-Means

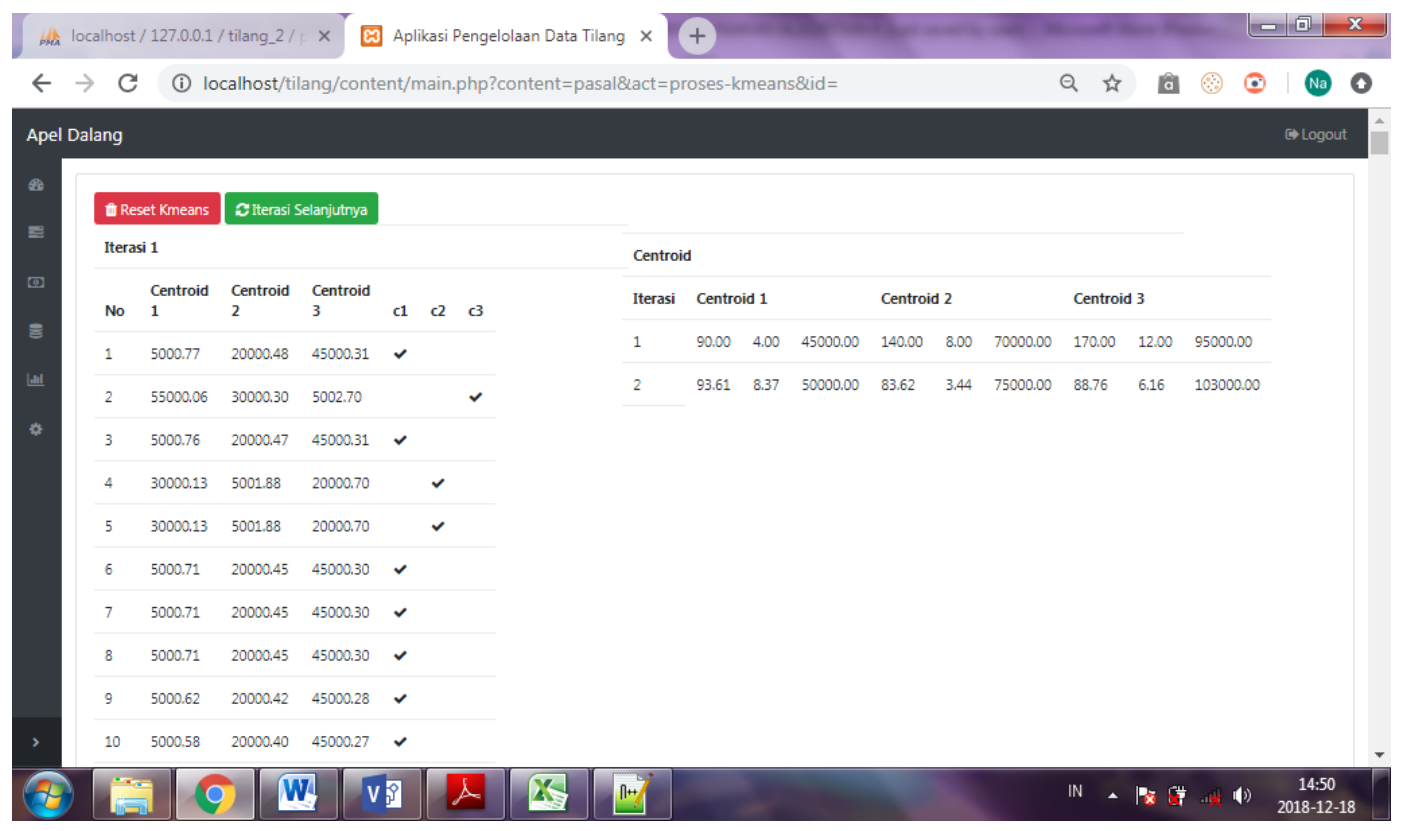

Gambar 11

Implementasi Halaman Proses Iterasi K-Means Clustering

\section{KESIMPULAN}

Kesimpulan dari penilitian yang telah dilakukan mengenai implementasi data mining unuk pengelompokan dengan algoritma K-Means adalah sebagai berikut :

a. Algoritma K-Means dengan metode clustering dapat digunakan dalam sistem pengelompokan data tilang.

b. Sistem pengelompokan data tilang dapat membantu pelayanan kepada masayarakat dan meningkatkan efektifitas pekerjaan di suatu Instansi sesuai dengan kebutuhan.. 


\section{DAFTAR PUSTAKA}

[1] F. Olaiya, "Application of Data Mining Techniques in Weather Prediction and Climate Change Studies," I.J. Inf. Eng. Electron. Bus., Vol. 1, 2012.

[2] W. K. V. Xindong, The Top Ten Algorithms in Data Mining, vol. XXXIII, no. 2. USA: Taylor \& Francis Group, LLC, 2009.

[3] Kamila, Insanul, Ulya Khairunnisa, Mustakim, " Perbandingan Algoritma K-Means dan K-Medoids untuk Pengelompokan Data Transaksi Bongkar Muat di Provinsi Riau,2015.

[4] Leskovec, Jure. Rajaraman, Anand. Jeffrey D. Ullman. , Mining of Massive Datasets, Stanford University, 2014.

[5] Ong, Johan Oscar . Implementasi algoritma k-means clustering untuk menentukan strategi marketing president university, LPPMUMS, 2013.

[6] Pressman, Roger, S., Maxim, Bruce R. Software Engineering : A Practitioner's Approach, 8th ed. , Mc Graw Hill, 2015.

[7] Suhariyanto, Budi, Pelenturan hukum dalam putusan peninjauan kembali yang diajukan oleh jaksa penuntut umum, Jurnal Yudisial, 2015.

[8] Suyanto, Dr., Data Mining untuk Klasifikasi dan Klasterisasi Data, Penerbit Informatika, 2017. 